\title{
Hubungan Derajat Celah Langit-Langit dengan Keadaan Telinga Tengah Berdasarkan Timpanogram pada Pasien Celah Langit-Langit
}

\author{
Shinta F. Boesoirie ${ }^{1}$, Nur A. Aroeman ${ }^{1}$, Dicki Nursyafri ${ }^{1}$, Vesara A. Gatera ${ }^{2}$ \\ ${ }^{1}$ Program Studi Kesehatan Telinga, Hidung, Tenggorok-Bedah Kepala dan Leher (THT-KL), \\ Fakultas Kedokteran, Universitas Padjadjaran, Sumedang, Indonesia, \\ ${ }^{2}$ Departemen Farmakologi dan Farmasi Klinik, Fakultas Farmasi, Universitas Padjadjaran, \\ Sumedang, Indonesia
}

\begin{abstract}
Abstrak
Celah langit-langit dan bibir sering terjadi akibat kegagalan penyatuan langit-langit dan bibir selama masa perkembangan janin. Sekitar $90 \%$ penderita celah langit-langit akan mengalami gangguan telinga tengah dan menimbulkan gangguan pendengaran. Kelainan telinga tengah pada penderita celah langitlangit pada derajat 2 umumnya terjadi pada obstruksi fungsional pada tuba eustakius sehingga terjadi kegagalan otot palatal untuk membuka tuba eustakius. Penelitian ini bertujuan untuk mengeksplorasi hubungan derajat celah langit-langit dengan keadaan telinga tengah pada pasien dengan celah langitlangit. Penelitian ini merupakan penelitian analitik observasional dengan rancangan potong lintang. Subjek penelitian adalah penderita celah langit-langit yang datang berobat ke poliklinik bedah mulut di YPPCBL Bandung dan poliklinik Telinga, Hidung, Tenggorok-Bedah Kepala dan Leher (THT-KL) pada tahun 2018 di Rumah Sakit Dr. Hasan Sadikin Bandung sebanyak 30 subjek. Data penelitian didapatkan dari anamnesis, pemeriksaan fisik THT-KL dan pemeriksaan timpanometri untuk mengetahui keadaan telinga tengah subjek penelitian. Data yang terkumpul dilakukan analisis data menggunakan uji regresi linear melalui nilai $\mathrm{p} \leq 0,05$ untuk melihat derajat hubungannya. Keadaan telinga tengah di kedua sisi memberikan gambaran semakin bertambah derajat celah langit-langit maka timpanogram lebih banyak tipe $\mathrm{B}$ diikuti dengan jumlah penderita celah abnormalnya. Dari 30 subjek penelitian, didapatkan sebanyak $20 \%$ pada derajat 3 dan $66,7 \%$ pada derajat 4 memiliki timpanogram tipe B di telinga kanan, sedangkan pada telinga kiri, didapatkan $6,7 \%$ pada derajat 2 memiliki tipmanogram tipe As, $20 \%$ pada derajat 3 dan $66,7 \%$ pada derajat 4 memiliki timpanogram tipe B. Disimpulkan bahwa terdapat hubungan yang bermakna antara derajat celah langit-langit dengan keadaan telinga tengah berdasarkan timpanogram.
\end{abstract}

Kata kunci: Celah langit-langit, derajat celah langit-langit, keadaan telinga tengah, timpanogram

\section{The Correlation Between the Cleft Palate Severity and the Middle Ear Condition Based on the Tympanogram in Cleft Palate Patients}

\begin{abstract}
Cleft lip and palate (CLP) are congenital anomalies caused by the failure of palate and lip fusion during fetal development which is influenced by numerous factors. Approximately $90 \%$ of CLP patients develop middle ear disorders leading to loss of hearing. Middle-ear disorders in cleft palate patients starting from grade 2, are bound to cause functional obstruction in the eustachian tube, due to the palatal muscle's failure to open the eustachian tube. This study, therefore, aimed to investigate the association between the cleft palate severity and the middle ear condition in these patients, using an analytic-observational method with a cross-sectional design. The study subjects were 30 cleft palate patients admitted to the oral surgery polyclinic at YPPCBL Bandung and ORL-HNS Polyclinic Dr. Hasan Sadikin General Hospital. Data were collected retrospectively from medical records, while ORL-HNS physical examination and tympanometry examination were performed to determine the middle ear condition. Subsequently, a regression analysis was conducted to determine the degree of association. According to the results, an increase in the cleft palate severity increases the prevalence of type-B tympanogram, with an increasing number of CLP patients. Among the study subjects, about $20 \%$ of grade 3 and $66.7 \%$ of grade 4 had type-B tympanogram in the right ear, while in the left ear, $6.7 \%$ of grade 2 had type-As tympanogram, and $20 \%$ of grade 3 , as well as $66.7 \%$ of grade 4 , had type-B tympanogram. Therefore, the cleft palate severity is significantly correlated with the middle ear condition, based on the tympanogram.
\end{abstract}

Keywords: Cleft palate, cleft palate severity, middle ear condition, tympanogram

Korespondensi: Dr. apt. Vesara A. Gatera, M.Farm., Departemen Farmakologi dan Farmasi Klinik, Fakultas Farmasi, Universitas Padjadjaran, Sumedang, Jawa Barat 45363, Indonesia, email: ardhegatera@gmail.com

Naskah diterima: 10 Februari 2021, Diterima untuk diterbitkan: 25 Mei 2021, Diterbitkan: 30 Juni 2021 


\section{Pendahuluan}

Kelainan telinga tengah dan gangguan pendengaran pada pasien dengan celah langitlangit terjadi akibat disfungsi tuba eustakius yang disebabkan oleh obstruksi fungsional karena kegagalan otot palatal untuk membuka tuba eustakius. Subramaniam dkk. dalam penelitiannya mengatakan bahwa insidensi gangguan pendengaran banyak terjadi pada anak dengan celah bibir dan langit-langit. Sebanyak 55\% penderita celah bibir dan langit-langit memiliki gangguan pendengaran terutama tipe konduktif mulai dari derajat ringan sampai sedang berat. Secara prevalensi, derajat ringan adalah derajat yang terbanyak diderita. $^{1-4}$

Kuo dkk. dalam penelitiannya menyatakan bahwa perkembangan prevalensi keadaan telinga tengah akan sesuai dengan derajat celah langit-langit dan dapat dipengaruhi oleh hal lain seperti otitis media efusi (OME). Hal yang sama juga diungkapkan oleh Schwartz dkk. dalam hasil penelitiannya bahwa keadaan telinga tengah akan dipengaruhi sebesar 25$74 \%$ menjadi tidak normal oleh peningkatan derajat celah langit-langit jika dibandingkan dengan seseorang tanpa celah langit-langit. ${ }^{5}$ Hal yang berbeda dilaporkan oleh Lithovius dkk. bahwa derajat celah langit-langit tidak memberikan dampak berarti terhadap keadaan telinga tengah. ${ }^{6}$

Celah bibir dan langit-langit merupakan kelainan kongenital yang paling sering terjadi di daerah mulut dan wajah yang disebabkan oleh multifaktorial, termasuk faktor lingkungan dan genetik. ${ }^{6,7}$ Kegagalan penyatuan ini akan menimbulkan kesulitan yang berhubungan dengan proses makan dan bicara, perkembangan bahasa, pertumbuhan gigi, perkembangan struktur wajah, dan proses mendengar. ${ }^{2}$

Celah bibir yang disertai dengan atau tanpa celah langit-langit terjadi pada 1 dari 700 kelahiran hidup dan sangat bervariasi tergantung pada letak geografis, ras, etnis, paparan lingkungan, dan status sosial ekonomi. Prevalensi kelainan kongenital ini di Asia dan Amerika dilaporkan terjadi pada 1 dari 500 kelahiran hidup, di negara Eropa 1 dari 1.000 kelahiran hidup, dan di negara Afrika 1 dari 2.500 kelahiran hidup. ${ }^{9}$ Berdasarkan data Yayasan Pembina Penderita Celah Bibir dan Langit-Langit (YPPCBL) di Bandung pada tahun 2012, prevalensi penderita celah bibir dan langit-langit yakni sebanyak 863 pasien dan lebih banyak ditemukan pada pria yakni sebanyak 557 pasien $(64,54 \%) .{ }^{10}$

Tata laksana pasien dengan celah bibir dan langit-langit terdiri dari tindakan pembedahan dan perawatan non-bedah yang dilakukan sejak lahir sampai dewasa. Tujuan dilakukan tindakan pembedahan pada pasien yaitu untuk memastikan terjadinya perkembangan yang normal dalam hal perkembangan struktur wajah dan penampilan pasien, pendengaran, bicara, dan bernapas. ${ }^{6}$ Penelitian ini bertujuan untuk mengetahui hubungan derajat celah langit-langit dengan keadaan telinga tengah pada pasien dengan celah langit-langit.

\section{Metode}

Penelitian ini merupakan penelitian analitik observasional dengan rancangan potong lintang. Subjek penelitian adalah penderita celah langit-langit yang datang berobat ke poliklinik bedah mulut di YPPCBL Bandung dan poliklinik Telinga, Hidung, TenggorokBedah Kepala dan Leher (THT-KL) di RSUP Dr. Hasan Sadikin dengan jumlah 30 subjek. Data penelitian diperoleh dari anamnesis, pemeriksaan fisik THT-KL dan pemeriksaan timpanometri untuk mengetahui keadaan telinga tengah subjek penelitian pada periode Februari-April 2018.

Penelitian ini berorientasi pada eksplorasi hubungan antara derajat celah langit-langit dengan gangguan telinga tengah berdasarkan gambaran timpanometri pada pasien dengan celah langit-langit. Studi dilakukan dengan 
pengukuran celah langit-langit yang dapat mengenai sekitar uvula saja atau bisa sampai mengenai seluruh langit-langit dari palatum mole sampai palatum durum. Indikator hasil pengukuran derajat celah langit-langit berdasarkan tingginya derajat celah (derajat 1-4). ${ }^{5,6,11,12}$ Keadaan telinga tengah diukur menggunakan metode timpanometri dengan merek interaoustic tipe AT235, indikator perlakuan dilakukan dengan mengamati nilai normal, tekanan telinga tengah normal (Tipe A), tekanan telinga sangat tinggi (Tipe Ad), tekanan telinga rendah (Tipe As), tidak adanya titik maksimum compliance (Tipe B), dan tekanan telinga negatif (Tipe C). ${ }^{13-16}$ Terakhir, diagnosis gangguan pada hidung berupa inflamasi mukosa hidung (rhinitis alergi) yang diukur melalui anamnesis, pemeriksaan fisik, nasoendoskopi dan tes kulit tusuk (skin prick test). ${ }^{17}$

Kategori subjek penelitian berdasar pada data pasein yang berobat ke poliklinik bedah mulut di YPPCBL Bandung dan poliklinik THT-KL di RSUP Dr. Hasan Sadikin selama periode penelitian dan memenuhi kriteria inklusi (pasien celah langit-langit dengan atau tanpa celah bibir usia $\leq 10$ tahun, belum pernah dilakukan tindakan pembedahan pada celah langit-langit dan belum pernah dilakukan pemasangan pipa ventilasi telinga di poliklinik bedah mulut YPPCBL Bandung dan poliklinik THT-KL RSUP Dr. Hasan Sadikin), dan bebas kriteria eksklusi (pasien perforasi membran timpani, otitis media akut, stenosis liang telinga dan infeksi saluran nafas bagian atas).

Analisis data meliputi analisis deskriptif dan statistik yang diolah menggunakan software IBM SPSS 20.0. Analisis statistik dilakukan melalui uji regresi linear untuk meninjau tingkat hubungan derajat celah langit-langit dengan keadaan telinga tengah berdasarkan gambaran timpanometri pada pasien dengan celah langit-langit. Kriteria kebermaknaan dinyatakan dengan nilai $p$ (sebesar 5\% atau 0,05) dan tingkat kepercayaan 95\% $(\alpha=5 \%){ }^{18}$ Penelitian ini mendapatkan persetujuan etik dari Komite Etik Penelitian Kesehatan RSUP Dr. Hasan Sadikin Bandung nomor LB.04.01/A05/EC/345/XI/2017.

\section{Hasil}

Pada penelitian ini, terdapat 30 pasien celah langit-langit dengan keadaan telinga tengah selama periode bulan Februari-April 2018, seluruh pasien sesuai dengan kriteria inklusi dan orang tua menyetujui anaknya untuk dijadikan subjek penelitian.

Gambaran karakteristik pasien dapat dilihat pada Tabel 1. Karakteristik subjek penelitian yang diambil dalam penelitian ini adalah usia, jenis kelamin dan diagnosis. Jenis kelamin mayoritas adalah laki-laki dengan persentase $76,7 \%$ dari total 30 pasien. Rata-rata usia subjek penelitian antara 3 bulan hingga 6 tahun adalah usia 7,23 tahun. Subjek penelitian paling banyak didiagnosis dengan

Tabel 1 Karakteristik Subjek Penelitian

\begin{tabular}{lcc}
\multicolumn{1}{c}{ Karakteristik Pasien } & Jumlah (n) & Persentase (\%) \\
\hline Jenis Kelamin & 23 & 76,7 \\
Laki-laki & 7 & 23,3 \\
Perempuan & & \\
Usia & 7.23 & \\
$\quad$ Rata-rata & 5.19 & 70,0 \\
$\quad$ Standar deviasi & & 30,0 \\
Diagnosis & 21 & \\
Celah langit-langit disertai dengan celah bibir & 9 & \\
Celah langit-langit & & \\
\hline
\end{tabular}


Tabel 2 Derajat Celah Langit-Langit dan Keadaan Telinga Tengah Subjek Penelitian Berdasarkan Timpanogram

\begin{tabular}{|c|c|c|}
\hline Karakteristik & Jumlah (n) & Persentase (\%) \\
\hline Derajat 1 & 0 & 0,0 \\
\hline Derajat 2 & 4 & 13,3 \\
\hline Derajat 3 & 6 & 20,0 \\
\hline Derajat 4 & 20 & 66,7 \\
\hline Keadaan Telinga Tengah & $f(n)$ & Persentase (\%) \\
\hline \multicolumn{3}{|l|}{ Kanan } \\
\hline A & 4 & 13,3 \\
\hline As & 0 & 0,0 \\
\hline $\mathrm{Ad}$ & 0 & 0,0 \\
\hline B & 26 & 86,7 \\
\hline $\mathrm{C}$ & 0 & 0,0 \\
\hline \multicolumn{3}{|l|}{ Kiri } \\
\hline A & 2 & 6,7 \\
\hline As & 2 & 6,7 \\
\hline $\mathrm{Ad}$ & 0 & 0,0 \\
\hline B & 26 & 86,7 \\
\hline $\mathrm{C}$ & 0 & 0,0 \\
\hline
\end{tabular}

celah langit-langit yang disertai dengan celah bibir sebanyak $70 \%$ dari total 30 pasien. Pada penelitian ini, penegakkan diagnosis rinitis alergi hanya dilakukan dengan anamnesis dan pemeriksaan rinoskopi anterior. Berdasarkan hasil pemeriksaan tersebut, tidak satupun subjek penelitian yang didapatkan rinitis alergi.

Berdasarkan Tabel 2, dapat dilihat bahwa dari 30 subjek penelitian, mayoritas subjek $(66,7 \%)$ memiliki celah langit-langit derajat 4 , dan keadaan telinga tengah baik yang kanan maupun kiri mayoritas memberikan hasil yang sama, yaitu sebanyak $86,7 \%$ memiliki timpanogram tipe B.

Berdasarkan hasil perhitungan Tabel 3, terdapat hubungan yang signifikan antara derajat celah langit-langit dengan keadaan telinga tengah bagian kanan. Hal ini dapat dilihat dari $p$-value yang kurang dari 0,05 dengan nilai kekuatan regresi sebesar 70,2\%.

Berdasarkan hasil perhitungan Tabel 4, terdapat hubungan yang signifikan antara

Tabel 3 Hubungan Derajat Celah Langit-Langit dengan Keadaan Telinga Tengah (Kanan)

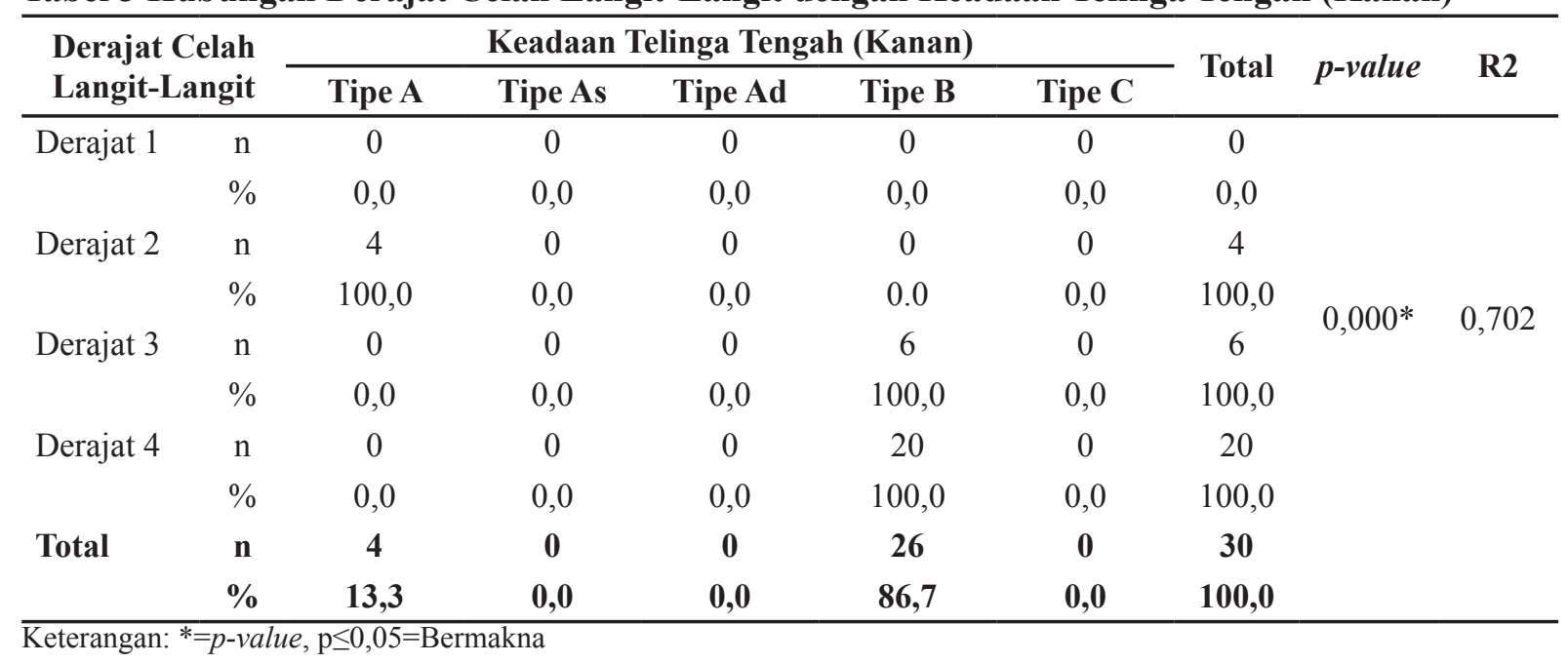


Tabel 4 Hubungan Derajat Celah Langit-Langit dengan Keadaan Telinga Tengah (Kiri)

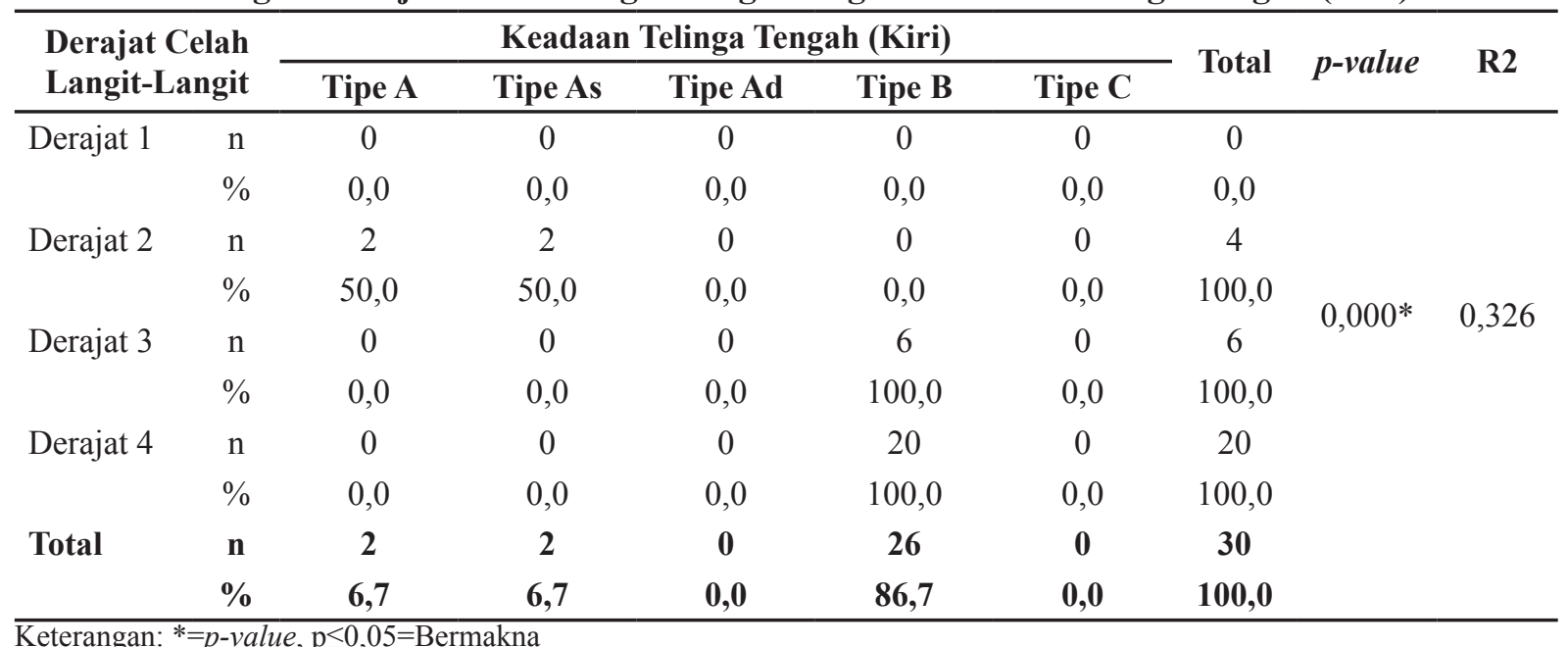

Keterangan: ${ }^{*}=p$-value, $\mathrm{p} \leq 0,05=$ Bermakna

derajat celah langit-langit dengan keadaan telinga tengah bagian kiri. Hal ini dapat dilihat dari $p$-value yang kurang dari 0,05 dengan nilai kekuatan regresi linear sebesar $32,6 \%$.

\section{Pembahasan}

Derajat celah langit-langit dan keadaan telinga tengah subjek

Derajat celah langit-langit terbanyak dari 30 subjek penelitian adalah derajat 4 yaitu sebanyak 20 pasien $(66,7 \%)$ dan tidak ada pasien yang didiagnosis celah langit-langit derajat 1. Hasil penelitian ini berbeda dengan hasil ppenelitian yang dilakukan oleh Hanny dkk. tahun 2016 di Belanda dengan jumlah sampel 271 pasien, yakni sebanyak 75 pasien $(27,7 \%)$ di antaranya menderita celah langitlangit derajat 1,63 pasien $(23,2 \%)$ menderita celah langit-langit derajat 2, 65 pasien $(24 \%)$ menderita celah langit-langit derajat 3 , dan 68 pasien $(25,1 \%)$ menderita celah langitlangit derajat 4. Perbedaan ini disebabkan oleh letak geografis, ras, dan etnis yang berbeda. ${ }^{11}$ Dilaporkan pula bahwa terjadi 1 dari 1.000 kelahiran bayi hidup dengan celah langit-langit yang disertai dengan celah bibir di seluruh dunia dan terjadi 1 dari 2.000 kelahiran bayi hidup hanya dengan celah langit-langit. Angka kejadian pada ras
Asia dikatakan lebih tinggi dibandingkan ras Kaukasia dan angka kejadian pada ras Afrika dikatakan yang paling rendah. ${ }^{9,11,19} \mathrm{Hal}$ ini dapat disebabkan oleh perbedaan pada ukuran prosesus frontonasal. Prosesus frontonasal yang lebih kecil seperti yang ditemukan pada ras Asia dan dikombinasi dengan struktur wajah bagian tengah yang lebih mendatar, bentuk kepala brachy-cephalic, dan langitlangit yang berbentuk elips, dapat menjadi penyebab tingginya tingkat kejadian celah langit-langit pada ras Asia. Sebaliknya, ras Afrika mempunyai struktur hidung yang lebih besar dan memberi gambaran bahwa prosesus frontonasal dan langit-langit pada ras Afrika lebih besar sehingga tingkat kejadian celah langit-langit pada ras ini lebih kecil. ${ }^{20}$

Hubungan derajat celah langit-langit dengan keadaan telinga tengah

Hubungan yang signifikan antara derajat celah langit-langit dengan keadaan telinga tengah pada kedua telinga. Hal ini dapat dilihat dari $p$-value yang kurang dari 0,05 di kedua telinga dengan nilai kekuatan regresi sebesar 70,2\% pada telinga kanan dan 32,6\% pada telinga kiri.

Kuo dkk. menyatakan bahwa prevalensi OME dan keadaan telinga tengah akan sesuai dengan derajat celah langit-langit. Hal yang 
sama juga diungkapkan oleh Schwartz dkk. dalam penelitiannya bahwa keadaan telinga tengah akan dipengaruhi $25-74 \%$ menjadi tidak normal oleh peningkatan derajat celah langit-langit dibandingkan dengan seseorang tanpa celah langit-langit. ${ }^{5}$ Kalaiarasi dkk. dalam penelitiannya mengatakan bahwa semakin minimal deformitas atau semakin kecil derajat keparahan celah abnormal seseorang maka semakin kecil pula risiko mengalami OME dan begitu juga sebaliknya. ${ }^{21}$

Otitis media efusi hampir ditemukan pada semua penderita celah langit-langit yang disertai atau tanpa celah bibir dengan prevalensi mencapai hampir $90 \%$. Patogenesis OME pada penderita celah langit-langit yang disertai atau tanpa celah bibir merupakan multifaktorial. Pada penderita celah langitlangit, orifisium tuba eustakius lebih kecil dan terletak lebih posteroinferior sehingga otot levator veli palatini akan menutup dan bukan membuka tuba eustakius selama fonasi atau menelan. Pada penderita tersebut juga sering terjadi refluks makanan atau minuman dari mulut ke kavum nasi karena insufisiensi velofaring sehingga mudah terjadi inflamasi dan edema pada orifisium tuba eustakius. Hal lain yang terjadi pada penderita ini di antaranya bertambah luasnya ruang nasofaring, perubahan pada lempeng medial pterigoid dan hamulus, saluran tuba eustakius yang pendek, bertambah lebar sudut antara bagian tulang rawan dari tuba eustakius dengan otot tensor veli palatini dan yang terpenting adalah ketidaknormalan dari tempat perlekatan otot tensor veli palatini dan otot levator veli palatini. ${ }^{5,6,22-25}$

Otot tensor veli palatini berasal dari samping sfenoid dan lateral dari fissura sfeno-petrosal pada bagian depan, dan dari dinding anterolateral tuba eustakius. Otot ini berbentuk segitiga terbalik dan semakin mengecil menjadi tendon datar yang membelok di sekitar hamulus pterygoideus. Sebagian kecil otot tersebut melekat ke tempat yang dekat dengan lempeng palatal dan sebagian besar otot tersebut akan berkembang seperti bentuk kipas sebelum masuk dan melekat ke aponeurosis palatina di palatum mole. Di tempat tersebut otot ini menjadi satu dengan serat otot sisi yang berlawanan. Sebagian dari serat otot tersebut yang letaknya paling dalam akan masuk ke dalam tulang rawan tuba eustakius. Fungsi utama otot tensor veli palatini yaitu berperan penting untuk membuka tuba eustakius. ${ }^{25-27}$

Otot levator veli palatini berjalan sesuai arah tuba eustakius. Otot ini berasal dari bagian apikal tulang petrosus dan dinding tulang rawan tuba eustakius. Fungsi otot ini akan bekerja sama dengan otot faring konstriktor superior untuk menutup apertura velo-faring. ${ }^{26,27}$ Pada beberapa penelitian menyatakan bahwa otot levator veli palatini juga berperan dalam membuka tuba eustakius. ${ }^{25}$

Dalam literatur baru-baru ini, terdapat konsensus yang menyatakan bahwa otot tensor veli palatini merupakan otot utama yang berperan dalam pembukaan tuba eustakius sehingga otot ini memegang peranan penting dalam ventilasi di telinga tengah. Pada penelitian yang dilakukan oleh Matsune dan Sando, didapatkan bahwa terdapat perbedaan yang sangat signifikan mengenai jumlah otot dan serat otot tensor veli palatini yang melekat pada aponeurosis palatina beserta rasio antara panjang tuba eustakius dengan lebar otot tensor veli palatini pada penderita celah langit-langit dengan yang bukan penderita. Pada penderita celah langit-langit, jumlah otot dan serat otot yang melekat pada aponeurosis palatina sangat sedikit dibandingkan dengan yang bukan penderita, sedangkan rasio antara panjang tuba eustakius dengan lebar otot tensor veli palatini sangat kecil pada penderita celah langit-langit dibandingkan dengan yang bukan penderita sehingga menyebabkan kurangnya gaya tarik dan menyebabkan disfungsi tuba eustakius. ${ }^{25}$ Pada celah langit derajat 1 otot yang mengalami destruksi hanya otot uvula saja dan pada derajat ini belum menimbulkan 
gangguan pada keadaan telinga tengah. Pada celah langit-langit derajat 2 , telah terjadi destruksi pada sebagian besar otot tensor veli palatini dan levator veli palatini sehingga pada derajat ini sudah mulai timbul gangguan pada keadaan telinga tengah, tetapi terkadang masih didapatkan keadaan telinga tengah yang normal. Pada celah langit-langit derajat 3 dan derajat 4, telah terjadi destruksi pada seluruh otot tensor veli palatini dan levator veli palatini sehingga pada derajat ini semua penderita akan mengalami gangguan pada keadaan telinga tengahnya. ${ }^{28}$ Patofisiologi terjadinya OME pada penderita celah langitlangit selain yang telah disebutkan di atas, yang terpenting juga adalah dengan semakin bertambahnya derajat celah langit-langit, maka lebar dari otot tensor veli palatini akan semakin mengecil dan perlekatan dari otot tersebut akan semakin melebar. Akibatnya, gaya tarik yang dihasilkan dari otot tersebut akan semakin berkurang pada tuba eustakius dan menyebabkan disfungsi tuba eustakius sehingga tekanan tuba eustakius penderita akan semakin negatif dan terjadilah efusi.

Pada penelitian yang dilakukan oleh Bantz dkk., disebutkan bahwa penyakit alergi pada awal kehidupan paling sering bermanifestasi pada kulit berupa dermatitis atopik, dan biasanya keadaan ini mulai muncul setelah lahir sampai usia 2 tahun yang nantinya akan berkembang menjadi penyakit asma dan rinitis alergi mulai usia 5 tahun. ${ }^{29}$ Prevalensi dermatitis atopik terjadi pada awal kehidupan, dermatitis atopik umumnya terjadi pada $3 \%$ orang dewasa dan relatif tinggi terjadi pada anak sebesar 30\%. Oleh karena itu, gangguan ini cenderung menurun seiring bertambahnya usia. ${ }^{30}$ Pada penelitian ini, sebanyak 93,3\% subjek penelitian berusia di bawah 2 tahun dan hanya $6,7 \%$ yang berusia di atas 2 tahun.

Keterbatasan dalam penelitian ini adalah tidak dilakukannya pemeriksaan penunjang untuk rinitis alergi yang dapat menimbulkan terjadinya OME. Hal ini dapat membuat rancu hasil interpretasi OME yang muncul pada penderita celah langit-langit yang disebabkan oleh celah abnormal atau akibat rinitis alergi.

\section{Simpulan}

Pada penelitian ini, terdapat hubungan derajat celah langit-langit dengan keadaan telinga tengah berdasarkan pengukuran timpanogram.

\section{Pendanaan}

Penelitian ini tidak didanai oleh sumber hibah manapun.

\section{Konflik Kepentingan}

Seluruh penulis menyatakan tidak terdapat potensi konflik kepentingan dengan penelitian, kepenulisan (authorship), dan atau publikasi artikel ini.

\section{Daftar Pustaka}

1. Flynn T, Möller C, Jönsson R, Lohmander A. The high prevalence of otitis media with effusion in children with cleft lip and palate as compared to children without clefts. Int J Pediatr Otorhinolaryngol. 2009;73(10):1441-6. doi: 10.1016/j.ijpo rl.2009.07.015

2. Thanawirattananit P, Prathanee B, Thanaviratananich S. Audiological status in patients with cleft lip and palate at Srinagarind Hospital. J Med Assoc Thail. 2012;95(11):S93-9. doi: 10.1016/j.ijporl. 2009.07.015

3. Subramaniam V, Manuprasad $\mathrm{S}$, Kallikkadan HH, Kumar VK. Otological and audiological manifestations in cleft lip and cleft palate children: A clinical study. Int J Otorhinolaryngol Head Neck Surg. 2015;1(1):7. doi: 10.18203/issn.245 4-5929.ijo hns20150579

4. Dhanasekaran SV, Joyce M, Govind 
K, Abilash K, Raja K. Assessment of eustachian tube function before and after cleft palate repair. Int $\mathrm{J}$ Med Heal Sci. 2015;4(4):462-6.

5. Kuo CL, Lien CF, Chu $\mathrm{CH}$, Shiao AS. Otitis media with effusion in children with cleft lip and palate: A narrative review. Int J Pediatr Otorhinolaryngol. 2013;77(9):1403-9. doi: 10.1016/j.ijporl. 2013.07.015

6. Lithovius RH, Lehtonen V, Autio TJ, Harila V, Anttonen V, Sándor GK, et al. The association cleft severity and cleft repair technique on hearing outcomes in children in northern Finland. J CranioMaxillo-Facial Surg. 2015;44(4):460-4. doi: 110.1016/j.jcms.2015.08.013

7. Kianifar H, Hasanzadeh N, Jahanbin A, Ezzati A, Kianifar H. Cleft lip and palate: A 30-year epidemiologic study in NorthEast of Iran. Iran J Otorhinolaryngol. 2015;27(78):35-41. doi: 10.22038/ijorl.2 015.3221

8. Kummer AW. Cleft palate \& craniofacial anomalies: Effects on speech and resonance, third edition. Boston: Cengage Learning; 2014.

9. Crockett DJ, Goudy SL. Cleft lip and palate. Facial Plast Surg Clin N Am. 2014;22(4):573-86. doi: 10.1016/j.fsc.20 14.07.002

10. Lesmana RSN. Prevalensi celah bibir dan langit-langit di Yayasan Pembina Penderita Celah Bibir dan Langit-langit (YPPCBL) Bandung tahun 2008-2012 (tesis). Bandung: Universitas Maranatha; 2013.

11. Hanny KH, de Vries IAC, Haverkamp SJ, Oomen KPQ, Penris WM, Eijkemans MJC, et al. Late detection of cleft palate. Eur J Pediatr. 2016;175(1):71-80. doi: 10.1007/s00431-015-2590-9

12. Andersson EM, Sandvik L, Åbyholm F, Semb G. Clefts of the secondary palate referred to the Oslo cleft team:
Epidemiology and cleft severity in 994 individuals. Cleft Palate-Craniofac J. 2010;47(4):335-42. doi: 10.1597/07-230.1

13. Kirtane MV, de Souza CE, Bantwal AR, Bewley AF, Beyea JA, Brackmann DE. Comprehensive diagnostic audiology. In: Otology and Neurotology. Verlagsgruppe: Thieme; 2013. doi: 10.1055/b-0034-805 26

14. Singleton AJ, Waltzman SB. Audiometric evaluation of children with hearing loss. Otolaryngol Clin North Am. 2015; 48(6):891-901. doi: 10.1016/j.otc.2015.0 6.002

15. Lous J. Why use tympanometry in general practice: A review. World J Otorhinolaryngol. 2015;5(2):53-7. doi: 10.5319/wjo.v5.i2.53

16. Rogers DJ, Boseley ME, Adams MT, Makowski RL, Hohman MH. Prospective comparison of handheld pneumatic otoscopy, binocular microscopy, and tympanometry in identifying middle ear effusions in children. Int $\mathrm{J}$ Pediatr Otorhinolaryngol. 2010;74(10):114-3. doi: 10.1016 /j.ijporl.2010.06.015

17. Bousquet J, Schünemann HJ, Togias A, Bachert C, Erhola M, Hellings PW, et al. Next-generation Allergic Rhinitis and Its Impact on Asthma (ARIA) guidelines for allergic rhinitis based on Grading of Recommendations Assessment, Development and Evaluation (GRADE) and real-world evidence. J Allergy Clin Immunol. 2020;145(1):70-80.e3. doi: 10. 1016/j.jaci.2019.06.049

18. Santosa PW, Hidayat A. Riset terapan: Teori dan aplikasi, $1^{\text {st }}$ edition. Jakarta: Globalstats Solusi Utama Jakarta; 2014.

19. Watkins SE, Meyer RE, Strauss RP, Aylsworth AS. Classification, epidemiology, and genetics of orofacial clefts. Clin Plast Surg. 2014;41(2):14963. doi: 10.1016/j.cps.2013.12.003

20. Burg ML, Chai Y, Yao CA, Magee III W, 
Figueiredo JC. Epidemiology, etiology, and treatment of isolated cleft palate. Front Physiol. 2016;7(March):1-16. doi: 10.3389/fphys.2016.00067

21. Kalaiarasi R, Syed KS, Vijayakumar C, Varghese AM, John M. Clinical study on middle ear diseases in children with orofacial clefts. Cureus. 2018;10(2): e2175. doi: $10.7759 /$ cureus. 2175

22. Rosenfeld RM, Shin JJ, Schwartz SR, Coggins R, Gagnon L, Hackell JM, et al. Clinical practice guideline. 2016:154(1); S1-41. doi: 10.1177/0194599815623467

23. Phua YS, Salkeld LJ, de Chalain TMB. Middle ear disease in children with cleft palate: Protocols for management. Int J Pediatr Otorhinolaryngol. 2009;73(2):307 -13. doi: 10.1016/j.ijporl.2008.10.026

24. Nasomtrug T, Chowchuen B, Surakulprabha P, Ratana-anekchai T, Thanawirattananit P. Time for eustachian tube function recovery in children with cleft palate after the 2-flap palatoplasty with intravelarveloplasty. J Med Assoc Thai. 2016;99(5):S97-105.

25. Heidsieck DSP, Smarius BJA, Oomen
KPQ, Breugem CC. The role of the tensor veli palatini muscle in the development of cleft palate-associated middle ear problems. Clin Oral Investig. 2016;20(7):1389-401. doi: 10.1007/s007 84-016-1828-x

26. Malek R. Cleft lip and palate. Lesions, pathophysiology and primary treatment. London: Martin Dunitz; 1999.

27. Leuwer R. Anatomy of the eustachian tube. Otolaryngol Clin North Am. 2016; 49(5):1097-106. doi: 10.1016/j.otc.2016. 05.002

28. Van Aalst JA, Kolappa KK, Sadove M. MOC-PSSM CME article: Nonsyndromic cleft palate. Plast Reconstr Surg. 2008; 121(1):1-14. doi: 10.1097/01.prs.000029 4706.05898.f3

29. Bantz SK, Zhu Z, Zheng T. The atopic march: Progression from atopic dermatitis to allergic rhinitis and asthma. J Clin Cell Immunol. 2014;5(2):202. doi: 10.4172/21 55-9899.1000202.

30. Weidinger S, Novak N. Seminar Atopic dermatitis. Lancet. 2016;387(10023):1109 -22. doi: 10.1016/S0140-6736(15)00149-X 